- Journal Publications • Research Consultancy

\title{
TRENDS IN AREA, PRODUCTION AND PRODUCTIVITY OF
}

\section{SUMMER PADDY IN CHHATTISGARH}

\author{
REENU SINGH ${ }^{1}$, RAVINDRA BRAHME $^{2} \&$ V. B. SINGH ${ }^{3}$ \\ ${ }^{1}$ Research Scholar, School of Studies in Economics, Pt. Ravishankar Shukla University, Chhattisgarh, India \\ ${ }^{2}$ Professor \& Head, School of Studies in Economics, Pt. Ravishankar Shukla University, Chhattisgarh, India \\ ${ }^{3}$ Professor \& Head, Department of Statistics, Rajmata Vijayaraje Scindia Krishi Vishwa Vidyalaya,
}

Gwalior, Madhya Pradesh, India

\begin{abstract}
The present study is going to examine the trends and variability in the growth of summer paddy in the Chhattisgarh. For the analysis, the relevant secondary data from 2000-01 to 2015-16 have been examined. The trend values were computed by OLS method by applying linear trend line equation while compound growth rate has been estimated with the help of exponential function and the variability by using the technique of coefficient of variation for convenience of comparison. The trend values for area, production, and productivity record that the cultivated area under summer paddy is increasing in all the agro-climatic zones (except northern hills zone) and in the state. However, production and productivity of summer rice in all the zones (except Bastar Plateau zone in the case of productivity) and in whole Chhattisgarh has been increasing during the period of study. The study concludes that a highly significant growth has been observed in case of area and production of summer rice in Chhattisgarh plains zone and in the state. Chhattisgarh plains zone held the largest share i.e. 90.69 to 97.96 per cent of the total cultivated area and 89.58 to 98.88 per cent of total production of summer rice in the state with higher productivity level. In regards to variability, the study concludes that there persist wide fluctuations in the growth of area, production, and productivity of summer rice over the study period in most of the zones and in the state. Increase in production was mainly due to significant increases in area under summer paddy cultivation.
\end{abstract}

KEYWORDS: Summer Paddy, Trend Values, Compound Growth Rate (CGR), Coefficient of Variation (CV), Area, Production \& Productivity

Received: Jun 21, 2018; Accepted: Jul 13, 2018; Published: Jul 28, 2018; Paper Id.: IJASRAUG201812

\section{INTRODUCTION}

India has made tremendous progress in agriculture over the past decades. Technological change with the introduction of short duration high yielding varieties of rice in the sixties increased the productivity of this crop manifold. However, rice production is increasing but is lagging behind population growth. Annual population growth rate of the country is nearly $1.8 \%$ and if per capita consumption of rice is expected to be $400 \mathrm{gm}$ of rice per day then the demand for rice in 2025 will be 130 million tonnes. India is the world's second largest producer of rice, after China and is now self- sufficient with substantial stock, which has transitioned itself from a nation dependent on imports to one feeding its population. Chhattisgarh state is known as "rice bowl' of the country. Out of the total cropped area, 70 per cent is used for paddy cultivation. Thus, Chhattisgarh occupies a very important place in rice production in India. As far as rice production is concerned, out of the total (all seasons) rice area (44.11 million ha) 
and production (105.48 million tonnes) in India, it was 4.04 million hectares and 7.83 million tonnes in $2014-15$ in Chhattisgarh. The share of area and production of Chhattisgarh was 9.16 per cent and 7.42 per cent respectively. Within a period of 16 years from 2000-01 to 2015-16, area, production, and productivity of summer rice in Chhattisgarh increased from 51.53 to 137.07 thousand hectares, 34.16 to 249.60 thousand tonnes and from 663 to $1821 \mathrm{~kg} / \mathrm{ha}$ showing an aggregate increase of $166.00,630.68$ and 174.66 per cent respectively.

Growth rates are widely employed in the field of agriculture as these have important policy implications. It is in this context that the present study aims at examining the growth rates in the area, production and productivity and their trend values of summer rice in the Chhattisgarh.

\section{METHODOLOGY}

The data collected were analyzed to draw meaningful interpretations and to assess the situation in the summer paddy economy in Chhattisgarh. Presently, Chhattisgarh consists of 27 districts. The limitation of this study is that the data information in terms of the number of years for some districts like Balodabazar, Gariaband, Balod, Bemetara, Mungeli, Surajpur, Balrampur, Kondagaon, Sukma, Narayanpur, and Bijapur is less because they are recently created. These districts therefore, have been merged in their parent districts. So effectively, the results of 16 districts are presented in the study. As per the agro-climatic zones, Chhattisgarh is divided into three agro-climatic zones namely, Northern Hills zone, Chhattisgarh plains zone, and Bastar plateau zone. These zones have huge variations in terms of soil topography, rainfall intensity and distribution, irrigation and adoption of the agricultural production system and thus they vary in the productivity of rice in these regions. Out of 16 districts, Northern Hills zone consists of three districts - Koriya, Surguja and Jashpur; Chhattisgarh plains zone consists of eleven districts - Kawardha, Bilaspur, Korba, Raigarh, Janjgir-Champa, Rajnandgaon, Durg, Raipur, Mahasamund, Dhamtari, and Kanker and Bastar Plateau zone consists of two districts namely Jagdalpur (Bastar) and Dantewada. The district wise data on area, production and productivity of summer paddy of the state was collected from various publications, official records and web sources. In order to calculate the trend values and compound growth rates, 16 years data from 2000-01 to 2015-16 were collected. The data have been analyzed with the help of statistical tools like percentage analysis, trend values by the method of least squares, Compound Growth rate, Arithmetic mean, Range and coefficient of variation.

\section{Trend Values}

The trend values for area, production and productivity were computed by Ordinary Least Squares (OLS) method by applying the following formula:

$\mathrm{Y}_{\mathrm{c}}=\mathrm{a}+\mathrm{bx}$

Where,

$\mathrm{Y}_{\mathrm{c}}=$ Trend values; $\mathrm{a}=$ intercept of the trend line; $\mathrm{b}=$ slope of the trend line

\section{Compound Growth Rate (CGR)}

By taking time as the independent variable and the area, production and productivity of the summer paddy as the dependent variable, the compound growth rates were estimated by using the formula:

$$
Y_{t}=a(1+r)^{t}
$$


Where,

$\mathrm{Y}_{\mathrm{t}}=$ Dependent Variable like area, production and productivity in the year ' $\mathrm{t}$ ' for which growth rate is estimated.

$\mathrm{a}=$ Constant

$\mathrm{r}=$ rate of annual increment

$\mathrm{t}=$ time element which takes the value of $1,2,3, \ldots, \mathrm{n}$

The above exponential equation can be expressed in terms of log forms as follows:

$\log Y_{t}=\log a+t \log (1+r)$

$\log \mathrm{Yt}=\log \mathrm{a}+\mathrm{t} \log \mathrm{b}$, where, $\mathrm{b}=1+\mathrm{r}$

By putting $\log \mathrm{Yt}=\mathrm{y}, \log \mathrm{a}=\mathrm{A}$ and $\log \mathrm{b}=\mathrm{B}$, the model becomes linear between $\mathrm{y}$ and $\mathrm{t}$, as $\mathrm{y}=\mathrm{A}+\mathrm{Bt}$,

Now, CGR per cent can be expressed as:

CGR in per cent $=($ Antilog $b-1) \times 100$

To test the significance of compound growth rate $t$ test has been used as follows:

$\mathrm{t}=\mathrm{r} / \mathrm{S} . \mathrm{E}(\mathrm{r})$ with $(n-2)$ degrees of freedom

Where,

S.E $(r)=100 \times b \times$ S.E. $(\log b) / 0.4343$

$\mathrm{r}=$ CGR per cent; $\mathrm{n}=$ number of years

\section{Productivity (Yield)}

The productivity (yield) was calculated by the following formula:

Productivity $($ Yield $)=$ Total production $/$ Total cultivated area

\section{Arithmetic Mean}

The mean (average) values were calculated by dividing the sum of Area/Production/Productivity by the number of years (16) taken for study.

\section{Coefficient of Variation (CV)}

The Coefficient of Variation (CV) was used as a measure of instability as:

$\mathrm{CV}=($ Standard deviation/Mean $) \times 100$

\section{RESULTS AND DISCUSSIONS}

The growth rate trends in the area, production and productivity depends on many factors. For example, the agricultural productivity in most cases depends on area sown under the crops and total production of that particular crop. The production of a crop not only depends on area sown under the crop but is also affected by technology adopted therein, entrepreneurship and economics of production. The trend values and compound growth rates (per annum in \%) of the area, production, and productivity of summer paddy at agro-climatic zone level of Chhattisgarh state were computed on the basis 
of 16 years secondary data (2000-01 to 2015-16) and are presented in Table-1 to 3.

Trend values (Table-1 to 3 ) for the area, production and productivity record that the cultivated area, under summer paddy is increasing in all the agro-climatic zones and in whole Chhattisgarh except northern hills zone. However, production of summer rice in Chhattisgarh plains zone, Bastar plateau zone and in whole Chhattisgarh including northern hills zone has been increasing during the period of study. All the agro-climatic zones except Bastar plateau have increased the summer rice productivity as the trend values (Table-3) are on the rise.

The compound growth rate (CGR) of the area under summer paddy cultivation (Table-1) in whole Chhattisgarh was 9.81 per cent per annum which was highly significant. Among all the climatic zones, only Chhattisgarh plains zone showed positive and highly significant CGR (10.30\% per annum) in respect of area cultivated under summer paddy. However, the area under summer paddy cultivation recorded positive and non-significant growth (2.96\% per annum) in Bastar plateau zone while negative and non-significant $(-0.85 \%$ per annum) in the northern hills zone. During the study period, the production of summer rice (Table-2) was increased at the compound rate of 13.14 per cent in Chhattisgarh plains zone, 12.65 per cent in whole Chhattisgarh, 1.70 per cent in Bastar plateau zone and 1.14 per cent per annum in northern hills zone. However, CGRs of summer rice production in northern hills and Bastar plateau zones were not found significant.

The CGR in productivity of summer rice (Table-3) showed positive growth rate at whole Chhattisgarh level, northern hills zone and Chhattisgarh plains zone, the values being 2.59, 1.03 and 2.58 per cent per annum respectively, but negative growth rate $(-1.22 \%$ per annum) in Bastar plateau zone, however, none of these values of CGR was significant. The CGR of area, production and productivity of summer paddy in Chhattisgarh plains zone was substantially high as compared to the remaining agro- climatic zones. All the zones taken together had registered growth rates of $9.81,12.65$ and 2.59 per cent per annum for area production and yield, respectively. Thus the growth in production of summer rice in the state as well as in agro-climatic zone Chhattisgarh plains has come mainly from the growth in the area than from the growth in productivity.

Coefficient of variation (\%) along will mean, minimum, maximum and range of area, production and productivity of summer paddy in different agro-climatic zones of Chhattisgarh were worked out and are presented in Table -4 .

The highest average area under summer paddy cultivation was held by Chhattisgarh plains zone with 112.69 thousand hectares followed by northern hills zone and Bastar plateau zone with 3.13 and 0.65 thousand hectares, respectively against the overall average area of 116.47 thousand hectares under summer paddy cultivation in the whole state. Chhattisgarh plains zone's minimum and maximum cultivated areas were 38.30 (2002-03) and 189.76 (2014-15) thousand hectares with the 45.99 per cent fluctuation in an area under study period. These values were the highest of the zones' respective values. The cultivated area under summer paddy in the state ranged from 42.33 (2002-03) to 194.17 (2014-15) thousand hectares with C.V. of 44.49 per cent.

In respect of productivity of summer rice, Chhattisgarh's average production was 227.04 thousand tonnes, and the minimum and maximum production were 34.16 (2000-01) and 449.73 (2012-13) thousand tonnes, respectively with 58.73 per cent of the variability in production of 16 years studied period. Among the agro-climatic zones, Chhattisgarh plains zone surpassed northern hills and Bastar plateau zones in the average, minimum and maximum production with the corresponding values of $221.69,31.33$ (2000-01) and 443.21 (2012-13) thousand tonnes. The coefficient of variation in 
production of northern hills, Chhattisgarh plains, and Bastar plateau zones were 36.55, 60.02 and 36.92 percentages, respectively.

As far as productivity of summer rice is concerned, Chhattisgarh plains zone's sixteen-year average productivity of $1876.64 \mathrm{~kg} / \mathrm{ha}$ was the highest of all the productivity values of rest of the two agro-climatic zones and whole Chhattisgarh state. Chhattisgarh plains zone's minimum and maximum productivity were 662.93(2000-01) and 3037.47 (2010-11) kilogram per hectare. These values were the highest of the rest of the two zones and state respective values. The coefficients of variation in productivity of summer rice were 30.14, 30.49, 27.40 and 30.11 per cent for northern hills, Chhattisgarh plains, Bastar plateau zones, and state, respectively.

\section{CONCLUSIONS}

On the basis of above discussions it is concluded regarding the trend values for area, production and productivity that the cultivated area under summer paddy is increasing in all the agro-climatic zones (except northern hills zone) and in the state. However, production and productivity of summer rice in all the zones (except Bastar Plateau zone in the case of productivity) and in whole Chhattisgarh has been increasing during the period of study. The study concludes that a highly significant growth has been observed in case of area and production of summer rice in Chhattisgarh plains zone and in the state. Chhattisgarh plains zone held the largest share i.e. 90.69 to 97.96 per cent of the total cultivated area and 89.58 to 98.88 per cent of total production of summer rice in the state with higher productivity level. In regards to variability, the study concludes that there persist wide fluctuations in the growth of area, production and productivity of summer rice over the study period in most of the zones and in the state. Increase in production of summer rice has largely been influenced by the increase in the area but in long terms this is not feasible as an area can only be increased up to a certain level. Measures need to be taken to improve the productivity of the summer rice so that its production can be increased without putting a pressure on the land resource.

\section{REFERENCES}

1. http://agridept.cg.gov.in/index.htm

2. Anonymous (2016). Agricultural Statistics at a Glance. Directorate of Economics and Statistics. Department of Agriculture and Cooperation, Ministry of Agriculture, Government of India.

3. Anonymos (2016). Ministry of Agriculture \& Farmers Welfare Department of Agriculture, Cooperation \& Farmers Welfare, Krishi Bhawan New Delhi.

4. Anonymous (2016). FAO. Rice Market Monitor and market division Food and Agriculture Organization of United Nations.

5. Anonymous (2016) Statistics, Department of Agriculture, Directorate of Agriculture, Raipur (C.G.).

6. Dhruw Y.S., D.K. Suryawanshi, and Prasad G. (2017). Constraints perceived and suggestions offered in adoption of summer rice production technology. International J. of Agri. Sci. 9(1):3619-3621.

7. Sivaraj, P., \& Philip, H. (2016). Role of mass media in changing awareness level on climate change among small and marginal paddy farmers of Tamil Nadu. Int J Humanities and Soc Sci Interventions, 5(4), 45-50.

8. Goyari Phanindra (2014). Irrigation difference and productivity variations in paddy cultivation: Field evidences from Udalguri district of Assam. Ind. Jn. of Agri. Econ. 69(1): 89-105.

9. Singh D.P. Deepak Kumar, M.S. Paikra and P.S. Kusro (2014). Developing statistical models to study the growth rates of 
paddy crops in different districts of Chhattisgarh. American International J. of Res. In Formal, Applied \& Natural Sciences. 5

(1): 102-104.

\section{APPENDICES}

Table 1: Trend Values for Area under Cultivation of Summer Paddy in Different Agro Climatic Zones of Chhattisgarh

\begin{tabular}{|c|c|c|c|c|}
\hline Year & $\begin{array}{c}\text { Total } \\
\text { Chhattisgarh }\end{array}$ & $\begin{array}{c}\text { Northern Hills } \\
\text { Zone }\end{array}$ & $\begin{array}{c}\text { Chhattisgarh } \\
\text { Plains Zone }\end{array}$ & $\begin{array}{c}\text { (in '000' ha) } \\
\text { Bartar Plateau } \\
\text { Zone }\end{array}$ \\
\hline $2000-01$ & 45.86 & 3.34 & 42.02 & 0.50 \\
\hline $2001-02$ & 55.28 & 3.31 & 51.44 & 0.52 \\
\hline $2002-03$ & 64.69 & 3.28 & 60.87 & 0.54 \\
\hline $2003-04$ & 74.11 & 3.26 & 70.29 & 0.56 \\
\hline $2004-05$ & 83.52 & 3.23 & 79.71 & 0.58 \\
\hline $2005-06$ & 92.94 & 3.20 & 89.13 & 0.60 \\
\hline $2006-07$ & 102.35 & 3.17 & 98.56 & 0.62 \\
\hline $2007-08$ & 111.77 & 3.15 & 107.98 & 0.64 \\
\hline $2008-09$ & 121.18 & 3.12 & 117.40 & 0.66 \\
\hline $2009-10$ & 130.60 & 3.09 & 126.83 & 0.68 \\
\hline $2010-11$ & 140.01 & 3.07 & 136.25 & 0.70 \\
\hline $2011-12$ & 149.43 & 3.04 & 145.67 & 0.72 \\
\hline $2012-13$ & 158.84 & 3.01 & 155.09 & 0.74 \\
\hline $2013-14$ & 168.25 & 2.98 & 164.52 & 0.76 \\
\hline $2014-15$ & 177.67 & 2.96 & 173.94 & 0.77 \\
\hline $2015-16$ & 187.08 & 2.93 & 183.36 & 0.79 \\
\hline \multicolumn{5}{|c|}{ Trend Coefficients } \\
\hline A & 36.45 & 3.3647 & 32.5998 & 0.4855 \\
\hline B & $9.4146 * *$ & -0.02718 & $9.4225^{* *}$ & 0.0193 \\
\hline R & 0.75 & 0.085 & 0.75 & 0.21 \\
\hline CGR $(\%)$ & $9.81 * *$ & -0.85 & $10.30 * *$ & 2.96 \\
\hline
\end{tabular}

Note: $* *$ - denotes significant at 1 per cent

Table 2: Trend Values for Production of Summer Paddy in Different Agro Climatic Zones of Chhattisgarh

( in ' 000 ' tonnes)

\begin{tabular}{|c|c|c|c|c|}
\hline Year & $\begin{array}{c}\text { Total } \\
\text { Chhattisgarh }\end{array}$ & $\begin{array}{c}\text { Northern Hills } \\
\text { Zone }\end{array}$ & $\begin{array}{c}\text { Chhattisgarh } \\
\text { Plains Zone }\end{array}$ & $\begin{array}{c}\text { Bastar Plateau } \\
\text { Zone }\end{array}$ \\
\hline $2000-01$ & 76.65 & 4.19 & 71.70 & 0.77 \\
\hline $2001-02$ & 96.71 & 4.22 & 91.70 & 0.79 \\
\hline $2002-03$ & 116.76 & 4.25 & 111.70 & 0.81 \\
\hline $2003-04$ & 136.81 & 4.28 & 131.70 & 0.83 \\
\hline $2004-05$ & 156.86 & 4.32 & 151.70 & 0.85 \\
\hline $2005-06$ & 176.91 & 4.35 & 171.70 & 0.86 \\
\hline $2006-07$ & 196.96 & 4.38 & 191.69 & 0.88 \\
\hline $2007-08$ & 217.01 & 4.41 & 211.69 & 0.90 \\
\hline $2008-09$ & 237.06 & 4.45 & 231.69 & 0.92 \\
\hline $2009-10$ & 257.11 & 4.48 & 251.69 & 0.94 \\
\hline $2010-11$ & 277.16 & 4.51 & 271.69 & 0.96 \\
\hline $2011-12$ & 297.21 & 4.54 & 291.69 & 0.98 \\
\hline $2012-13$ & 317.26 & 4.57 & 311.69 & 1.00 \\
\hline $2013-14$ & 337.31 & 4.61 & 331.69 & 1.02 \\
\hline $2014-15$ & 357.37 & 4.64 & 351.69 & 1.04 \\
\hline $2015-16$ & 377.42 & 4.67 & 371.69 & 1.06 \\
\hline \multicolumn{5}{|r|}{ Trend Coefficients } \\
\hline A & 56.6042 & 4.1555 & 51.7 & 0.7487 \\
\hline
\end{tabular}




\begin{tabular}{|c|c|c|c|c|}
\hline \multicolumn{5}{c}{ Table 2: Contd., } \\
\hline $\mathrm{B}$ & $20.0507 * *$ & 0.0322 & $19.9992 * *$ & 0.0193 \\
\hline $\mathrm{R}^{2}$ & 0.51 & 0.009 & 0.51 & 0.075 \\
\hline CGR $(\%)$ & $12.65 * *$ & 1.14 & $13.14 * *$ & 1.70 \\
\hline
\end{tabular}

Note: $* *$ - denotes significant at 1 per cent

Table 3: Trend Values for Yield (Productivity) of Summer Paddy in Different Agro Climatic Zones of Chhattisgarh

\begin{tabular}{|c|c|c|c|c|}
\hline Year & $\begin{array}{c}\text { Total } \\
\text { Chhattisgarh }\end{array}$ & $\begin{array}{l}\text { Northern } \\
\text { Hills Zone }\end{array}$ & $\begin{array}{l}\text { Chhattisgarh } \\
\text { Plains Zone }\end{array}$ & $\begin{array}{c}\text { Bastar Plateau } \\
\text { Zone }\end{array}$ \\
\hline $2000-01$ & 1586.30 & 1309.09 & 1600.41 & 1600.55 \\
\hline 2001-02 & 1623.04 & 1317.04 & 1637.24 & 1578.18 \\
\hline 2002-03 & 1659.78 & 1324.99 & 1674.07 & 1555.81 \\
\hline 2003-04 & 1696.53 & 1332.94 & 1710.90 & 1533.45 \\
\hline 2004-05 & 1733.27 & 1340.89 & 1747.73 & 1511.08 \\
\hline 2005-06 & 1770.02 & 1348.84 & 1784.56 & 1488.72 \\
\hline $2006-07$ & 1806.76 & 1356.79 & 1821.39 & 1466.35 \\
\hline $2007-08$ & 1843.50 & 1364.74 & 1858.22 & 1443.98 \\
\hline 2008-09 & 1880.25 & 1372.69 & 1895.05 & 1421.62 \\
\hline $2009-10$ & 1916.99 & 1380.64 & 1931.88 & 1399.25 \\
\hline $2010-11$ & 1953.74 & 1388.59 & 1968.72 & 1376.88 \\
\hline 2011-12 & 1990.48 & 1396.54 & 2005.55 & 1354.52 \\
\hline $2012-13$ & 2027.22 & 1404.49 & 2042.38 & 1332.15 \\
\hline 2013-14 & 2063.97 & 1412.44 & 2079.21 & 1309.79 \\
\hline 2014-15 & 2100.71 & 1420.39 & 2116.04 & 1287.42 \\
\hline $2015-16$ & 2137.46 & 1428.34 & 2152.87 & 1265.05 \\
\hline \multicolumn{5}{|c|}{ Trend Coefficients } \\
\hline $\mathrm{A}$ & 1549.553 & 1301.136 & 1563.574 & 1622.913 \\
\hline $\mathrm{B}$ & 36.7439 & 7.95033 & 36.8311 & -22.3662 \\
\hline $\mathrm{R}^{2}$ & 0.10 & 0.007 & 0.094 & 0.074 \\
\hline CGR $(\%)$ & 2.59 & 1.03 & 2.58 & -1.22 \\
\hline
\end{tabular}

Table 4: Descriptive Statistics for Area, production and Productivity of Summer Paddy in Different Agro Climatic Zones of Chhattisgarh

\begin{tabular}{|l|c|c|c|c|c|}
\hline \multirow{2}{*}{ Variables } & \multicolumn{5}{|c|}{ Descriptive Statistics } \\
\cline { 2 - 6 } & Mean & Minimum & Maximum & Range & $\begin{array}{c}\text { CV } \\
\text { (\%) }\end{array}$ \\
\hline \multicolumn{7}{|c|}{ Northern Hills Zone } \\
\hline Area ('000' ha) & 3.13 & 2.43 & 3.76 & 1.33 & 14.15 \\
\hline Production ('000' tonnes) & 4.43 & 2.00 & 6.74 & 4.74 & 36.55 \\
\hline Yield (kg/ha) & 1400.63 & 635.36 & 2073.85 & 1438.49 & 30.14 \\
\hline \multicolumn{7}{|c|}{ Chhattisgarh Plains Zone } \\
\hline Area ('000' ha) & 112.69 & 38.30 & 189.76 & 151.46 & 45.99 \\
\hline Production ('000' tonnes) & 221.69 & 31.33 & 443.21 & 411.88 & 60.02 \\
\hline Yield (kg/ha) & 1876.64 & 662.93 & 3037.47 & 2374.54 & 30.49 \\
\hline \multicolumn{7}{|c|}{ Bastar Plateau Zone } \\
\hline Area ('000' ha) & 0.65 & 0.33 & 1.16 & 0.83 & 30.68 \\
\hline Production ('000' tonnes) & 0.91 & 0.50 & 1.74 & 1.24 & 36.92 \\
\hline Yield (kg/ha) & 1432.80 & 815.38 & 2060.00 & 1244.62 & 27.40 \\
\hline & 116.47 & 42.23 & 194.17 & 151.94 & 44.49 \\
\hline Area ('000' ha) & 227.04 & 34.16 & 449.73 & 415.57 & 58.73 \\
\hline Production ('000' tonnes) & 1861.88 & 662.91 & 2998.60 & 2335.69 & 30.11 \\
\hline Yield (kg/ha)
\end{tabular}


